\begin{tabular}{|c|c|c|c|c|c|c|}
\hline \multirow{4}{*}{ Impact Factor: } & ISRA (India) & $=3.117$ & SIS (USA) & $=0.912$ & ICV (Poland) & $=6.630$ \\
\hline & ISI (Dubai, UAI & $=0.829$ & РИНЦ (Russia & $=0.156$ & PIF (India) & $=1.940$ \\
\hline & GIF (Australia) & $=0.564$ & ESJI (KZ) & $=5.015$ & IBI (India) & $=4.260$ \\
\hline & JIF & $=1.500$ & SJIF (Morocce & $=5.667$ & & \\
\hline
\end{tabular}

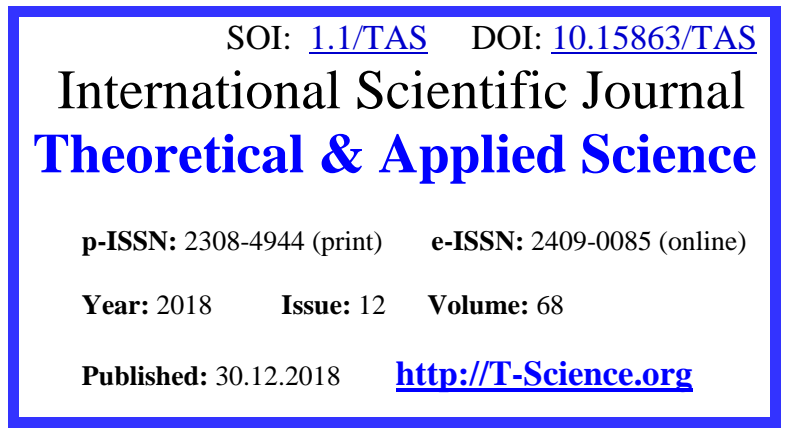

\section{THE ROLE OF HUMAN GENOME RELATED LEGAL STUDY DEVELOPMENT}

QR - Article

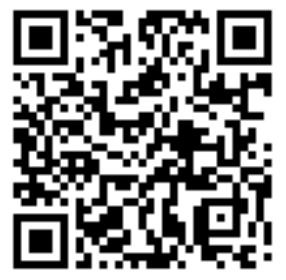

Azhar Nartai

PhD student of «Jurisprudence»

Department of Social Science

Faculty in International Kazakh-

Turkish University after H.A.Yessevi sarapshy.tk@mail.ru

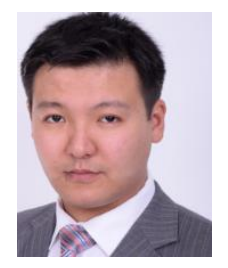

Yernar Sailaubekovich Shalkharov

$\mathrm{PhD}$ doctor of «Jurisprudence»

Department of Social Science

Faculty in International KazakhTurkish University after H.A.Yessevi yernar_shalkharov@bk.ru

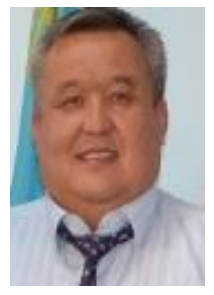

Kairat Turlybaevich Bitemirov Candidate of law science., ass.professor Chief of «Jurisprudence» Department of Social Science Faculty in International KazakhTurkish University after H.A.Yessevi bitemirov_kayrat@mail.ru

Abstract: The century of rapidly developing technologies determines the need for a component for society at the moment when it most needs it. So today, undergoing a crisis of shortage of donor organs for transplantation, search for a suitable blood group for transfusion, issues of implantation, removal of a cancerous tumor, purification of blood serum components and other problems push humanity to reach new heights in solving such unsolvable problems. One of these solutions is biotechnology for the study of the human genome. Having successfully reproduced numerous clones of animals, mankind wondered how realistic it is to reproduce a living person for use in accordance with the need to solve global problems. The present has spawned many discussions on the part of theologians, ethics, biologists, medical workers and other segments of the population. The legal position is also among them. Since all decisions taken in a modern state should be regulated and covered in the system of regulatory legal acts, two positions were legally manifested. The first position implies an urgent need to depressurize in detail all the components associated with the study of the genome at the legislative level. The second position implies a number of sanctions related to illegal activities in the field of the study of the genome. This article discusses both positions.

Key words: genome, exogenous, genetic material, stem cells, DNA, RNA, amino acids, imbalance, mutation, evolution, gene technology, biotechnology.

Language: English

Citation: Nartai, A., Shalkharov, Y. S., \& Bitemirov, K. T. (2018). The role of human genome related legal study development. ISJ Theoretical \& Applied Science, 12 (68), 290-292.

Soi: http://s-o-i.org/1.1/TAS-12-68-43 Doi: crossef https://dx.doi.org/10.15863/TAS.2018.12.68.43

\section{Introduction}

When considering the development of the legal institution of the human genome by the example of the Republic of Kazakhstan, it is possible to designate first of all the norms of the Constitution of the
Republic of Kazakhstan, in accordance with which everyone has the right to life (1). At the same time, it can be noted that the Constitution does not stipulate that it is the citizen who has the right to life, leaving space in perspective to add other subjects equal to 


\begin{tabular}{|c|c|c|c|c|c|c|}
\hline \multirow{4}{*}{ Impact Factor: } & ISRA (India) & $=3.117$ & SIS (USA) & $=0.912$ & ICV (Poland) & $=6.630$ \\
\hline & ISI (Dubai, UAE & $=0.829$ & РИНЦ (Russia) & $=0.156$ & PIF (India) & $=1.940$ \\
\hline & GIF (Australia) & $=0.564$ & ESJI (KZ) & $=\mathbf{5 . 0 1 5}$ & IBI (India) & $=4.260$ \\
\hline & JIF & $=1.500$ & SJIF (Morocco) & $=5.667$ & & \\
\hline
\end{tabular}

citizens and people. The present implies consideration of people, not only from the point of view of the newborn, as was previously accepted, but also at the stage of both embryos and biological material, the norms of which were covered in specialized health legislation (2). Thus, in support of world policy on the protection of the rights of genetic material, the purpose of which is to prevent the cloning of a living person in the criminal law of the Republic of Kazakhstan in the new edition outlined the responsibility for human cloning for industrial, commercial and other purposes linking this by analogy with the export of embryos and genetic material beyond territory of the Republic (3). The present was generated on the basis of public position to consider human genetic material, in case of its successful reproduction, as a result of intellectual activity, which is also indicated in the civil legislation of the Republic of Kazakhstan as one of the objects of intellectual activity (4). It is the ethical side of this issue of considering the rights and freedoms of an artificially reproduced embryo that was analyzed at the International Congress on Education, Science and Culture, where the main focus was on the question of the role of development of the human genetics institute in modern society (5).

\section{Materials and Methods}

Theoretical studies on the role of development of the legal study of the genome, conducted in the Republic of Kazakhstan, have shown that today the first attempt to identify genetic manipulations on the human genome has been legally made in criminal legislation, explaining this prerogative of the sanction, which will first limit chaotic research on manipulations on the genome man, then to systematize in a specific order (6). However, the same author considered another position, according to which prohibitive actions on the part of the state can be regarded as a restriction in progress for citizens whose freedom of intellectual activity is constitutionally guaranteed rights and freedoms (7). Freedom of a citizen's will, together with his ability to solve any intellectual tasks not only at the micro state level, but also at the macro state level, makes his activity not only constitutionally protected, but also encouraging from the state, for which certain funding is allocated from the state (8). However, the most controversial question remains whether to develop genetic studies on the human genome, as this can solve many intractable issues in the field of transplantology, immunology, oncology, and others, or remain committed to traditional views from considerations of theology and ethics (9). The present has become relevant since, according to some assumptions, a born clone, with its full identity, becomes the property of the patented technology and the patentee as a whole, which implies slavery, which negatively affects the development of society, returning humanity to the slave system (10).

Fundamental questions of considering the role of the legal study of the genome in Russia showed a different position, according to which genetic material is not entirely an object of property, since it is more a component of health, which proves the consideration of infertility as an element of health (11). Nevertheless, with the development of reproductive technologies, mankind has learned to preserve, stabilize and even modernize cells in stored data, which already today are freely in circulation, which in turn proves the possibility of considering genetic material as an object of property (12). Consequently, it is not even the ethical question whether it is legitimate to appropriate rights and freedoms to an effectively raised clone, but how right it is to trade your cells on the open market (13). However, already today human organs and tissues are in free circulation on the example of selling hair (14). Therefore, a common denominator can be the classification of objects of genetic material depending on the origin, content and form (15).

American studies have differently outlined the position regarding the issues of consideration of human genetic material in the system of functioning objects. This implies that if Russian legislation considers human genetic material as a component of citizens' health, then American law does not exclude the possibility of considering the human genome as a different object in accordance with the state's problems (16). That is, given the existing problem and progressive advanced research in the field of genetic engineering, American legislation does not exclude the possibility of considering it as a result of intellectual property to create a certain level of encouragement of national research, and as a form of ownership for the industrial circulation of genetic material in world markets (17). At the same time, it should be noted that in the field of in vitro fertilization in the global legal space of the United States and Western Europe, there have already been precedents regarding disputes over the ownership of the genetic material of specific human individuals (18). The present shows the problematics of the legal classification of the human genome as an object of law (19). This makes it necessary now to characterize the legal status of the human genome and its components in the system of current legislation (20). 


\begin{tabular}{|c|c|c|c|c|c|c|}
\hline \multirow{4}{*}{ Impact Factor: } & ISRA (India) & $=3.117$ & SIS (USA) & $=0.912$ & ICV (Poland) & $=6.630$ \\
\hline & ISI (Dubai, UAE & $=0.829$ & РИНЦ (Russia & $=\mathbf{0 . 1 5 6}$ & PIF (India) & $=1.940$ \\
\hline & GIF (Australia) & $=0.564$ & ESJI (KZ) & $=5.015$ & IBI (India) & $=4.260$ \\
\hline & JIF & $=1.500$ & SJIF (Morocco & $=5.667$ & & \\
\hline
\end{tabular}

\section{Conclusion}

In conclusion, it can be stated that the uncontrolled development of genetic engineering in relation to the human genome is an unfavorable factor for the development of all branches of citizens' life activity, with which a citizen interacts in professional life, in life and in personal life. Consequently, genetic engineering and models of the functioning of elements of genetic engineering must be strictly fixed at the normative level, starting from genetic material.

\section{References:}

1. (n.d.). Constitution of the Republic of Kazakhstan, Article 115.

2. (n.d.). KRK “on People's Health and the Healthcare System”, Article 1, Part 1, Subpart 57-2.

3. (n.d.). Criminal Code of the Republic of Kazakhstan, Article 129, part 1.

4. (n.d.). Civil Code of the Republic of Kazakhstan, Article 961, part 1.

5. (n.d.). Universal Declaration on the Human Genome and Human Rights, adopted on 11 November 1997 by the General Conference of the United Nations Educational, Scientific and Cultural Organization, Article 12, part a.

6. Shalkharov, Y. S. (n.d.). Gene canning of a person in the system of criminal law. Short communication. In press in Germany.

7. Shalkharov, Y. S. (n.d.). Legal status of gender engineering objectives. Short communication. In press in Germany.

8. Shalkharov, Y. S. (n.d.). Descriptions of the rights in the field of general engineering. Short communication. In press in Germany.

9. Shalkharov, Y. S. (n.d.). DNA dactoscopation on gene: legal issues. Short communication. In press in Germany.

10. Shalkharov, Y. S. (n.d.). World experience DNA legal status analysis. Short communication. In press in Germany.

11. Nikitina, A. E. (2002). Pravovoe regulirovanie biomedicinskih tehnologij :Teoretiko-pravovoj aspekt. Dissertacija zashhishhennaja v 2002 godu v Sankt-Peterburge. Kod VAK 12.00.01, p.283.

12. Isaeva, J. L., \& Batasheva, M. A. (n.d.). Jetikopravovye aspekty vmeshatel'stva $\mathrm{v}$ genom cheloveka. Jelektronnyj nauchno-prakticheskij zhurnal «Sovremennye nauchnye issledovanija $i$ innovacii»., ISSN 2223-4888.
13. Polikarpova, V. A. (2005). Gennaja inzhenerija i prava cheloveka. Izvestija JuFU. Tehnicheskie nauki.

14. Lagovskij, V. (2016, February 03). Pojavjatsja li «otredaktirovannye» ljudi? Komsomol'skaja pravda. Retrieved November 23, 2016, from http://www.kazan.kp.ru/daily/26488/3357863

15. Krasovskij, V. S., Ermolaev, D. O., \& Ermolaeva, J. N. (2015). Biomedicinskij jeksperiment s uchastiem cheloveka: rossijskij vzgljad na problem. Nauchnyj al'manah, №11 4(13).

16. Christoforos, Nikolaou. (2014, December). Menzerath-Altmann law in mammalian exons reflects the dynamics of gene structure evolution. Research article., Computational Biology and Chemistry, Volume 53, Part A, 134143

17. Nacher, J. C., \& Ochiai, T. (2008, September 29). Power-law distribution of gene expression fluctuations. Short communication., Physics Letters A, Volume 372, Issue 40, 6202-6206.

18. Nacher, J. C., \& Akutsu, T. (2006, December 18). Sensitivity of the power-law exponent in gene expression distribution to mRNA decay rate. Short communication., Physics Letters A, Volume 360, Issue 1, 174-178.

19. Hughes, T., Liberles, D. A. (2008, May 15). The power-law distribution of gene family size is driven by the pseudogenisation rate's heterogeneity between gene families. Research article, Gene, Volume 414, Issues 1-2, 85-94.

20. Cook, J. (2019). Emery and Rimoin's Principles and Practice of Medical Genetics and Genomics (Seventh Edition), (pp. 201-225). Book chapter., 7: Genes in Families., 